\title{
3D models related to the publication: Early Oligocene chinchilloid caviomorphs from Puerto Rico and the initial rodent colonization of the West Indies
}

\author{
Laurent MARIVAUX ${ }^{*}$, Jorge VÉLEZ-JUARBE², Pierre-Olivier ANTOINE ${ }^{1}$ \\ ${ }^{1}$ Institut des Sciences de l'Évolution de Montpellier (ISE-M, UMR 5554, CNRS/UM/IRD/EPHE), c.c. 064, Université de Montpellier, place Eugène \\ Bataillon, 34095 Montpellier Cedex 05, France \\ ${ }^{2}$ Department of Mammalogy, Natural History Museum of Los Angeles County, 900 Exposition Boulevard, Los Angeles, CA 90007, USA \\ *Corresponding author: Laurent.Marivaux@UMontpellier.fr
}

\begin{abstract}
This contribution contains the 3D models of the fossil teeth of two chinchilloid caviomorph rodents (Borikenomys praecursor and Chinchilloidea gen. et sp. indet.) discovered from lower Oligocene deposits of Puerto Rico, San Sebastian Formation (locality LACM Loc. 8060). These fossils were described and figured in the following publication: Marivaux et al. (2020), Early Oligocene chinchilloid caviomorphs from Puerto Rico and the initial rodent colonization of the West Indies. Proceedings of the Royal Society B. http://dx.doi.org/10.1098/rspb.2019.2806
\end{abstract}

Keywords: Caribbean islands, Caviomorpha, Paleobiogeography, Paleogene, Rodentia

Submitted:2020-08-21, published online:2020-09-07. https://doi.org/10.18563/journal.m3.127

\section{INTRODUCTION}

We present here the 3D digital models of three dental remains of fossil rodents (Fig. 1; Table 1) that were recently unearthed in shallow marine Oligocene deposits ( $29.5 \mathrm{Ma}$; San Sebastian Formation) at locality LACM Loc. 8060, situated on the west bank of Río Guatemala, San Sebastián, Puerto Rico (VélezJuarbe et al., 2007, 2014; Ortega-Ariza et al., 2015; Marivaux et al., 2020). Two specimens (a complete lower molar [LACM 162447; Fig. 1A-C] and a half lower molar [LACM 162446; Fig. 1D-F]) have allowed the description of a new small-bodied chinchilloid caviomorph (Borikenomys praecursor Marivaux et al., 2020). Although fragmentary, the third dental specimen (LACM 162448; Fig. 1G-I) documents a distinctively larger species, also referred to as a chinchilloid (Marivaux et al., 2020). These Puerto Rican fossil chinchilloids are of undisputable South American origin, and represent the earliest West Indian rodents known thus far. This find has substantial biogeographic implications since it attests to an early dispersal of land mammals from South America to the West Indies, perhaps via the emergence of the Aves Ridge that occurred ca. 35-33 Ma (GAARlandia hypothesis; MacPhee \& Iturralde-Vinent, 1995, 2005; Iturralde-Vinent \& MacPhee, 1999). Considering both this new paleontological evidence and recent molecular divergence estimates (Brace et al., 2015; Courcelle et al., 2019), the natural colonization of the West Indies by rodents likely occurred through multiple and time-staggered dispersal events (chinchilloids, then echimyid octodontoids [spiny rats/hutias], caviids, and lastly oryzomyin muroids [rice rats]) in the last 35 million years. This find has also raised the critical question of a possible link between these Oligocene Puerto Rican chinchilloids and some of the Pleistocene-Holocene West Indian

$\begin{array}{ccl}\text { Inv nr. } & \begin{array}{c}\text { Taxon } \\ \text { LACM 162447 } \\ \text { praecursor } \\ \text { porikenomys } \\ \text { praecursor }\end{array} & \begin{array}{l}\text { Description } \\ \text { Right lower m3. }\end{array} \\ \text { LACM 162446 } & \begin{array}{l}\text { Fragment of } \\ \text { lower molar } \\ \text { (most of the } \\ \text { mesial part). }\end{array} \\ \text { LACM 162448 } & \begin{array}{c}\text { Chinchilloidea } \\ \text { gen. et sp. indet }\end{array} & \begin{array}{l}\text { Fragment of } \\ \text { either an upper } \\ \text { tooth (mesial } \\ \text { laminae) or a } \\ \text { lower tooth (distal } \\ \text { laminae). }\end{array}\end{array}$

Table 1. List of 3D models. All specimens belong to the collections of the Natural History Museum of Los Angeles, California, USA.

"giant hutias" (Amblyrhiza Cope, 1868 and Elasmodontomys Anthony, 1916), for which a chinchilloid status is also strongly supported in the framework of that study (Marivaux et al., 2020). Although the pre-Pleistocene evolutionary history of these endemic "giant hutias" remains so far undocumented, lineages of these iconic recently-extinct rodents could have a very great antiquity on the islands, extending back more than 30 million years (as also recently demonstrated for West Indian sloths and coquí frogs; Delsuc et al., 2019; Presslee et al., 2019; Blackburn et al., 2020).

\section{METHODS}

Each specimen was scanned with a resolution of $6 \mu \mathrm{m}$ using a $\mu$-CT scanning station EasyTom 150 / Rx Solutions (Montpellier Ressources Imagerie, ISE-M, Montpellier, France). AVIZO 7.1 (Visualization Sciences Group) software was used for vi- 
sualization, segmentation, and 3D rendering. The isolated teeth and fragment of teeth were prepared within a "labelfield" module of AVIZO, using the segmentation threshold selection tool. The 3D models are provided in ".ply" format, and thus can be opened with a wide range of softwares (e.g., MorphoDig, an open-source 3D freeware (Lebrun, 2018; https: //morphomuseum.com/Pages/morphodig).

\section{ACKNOWLEDGEMENTS}

The 3D data presented in this work were produced through the technical facilities of the Montpellier RIO Imaging (MRI) platform (ISE-M, Université de Montpellier) and of the LabEx CeMEB. We particularly thank R. Lebrun and A.-L. Charruault (ISE-M, Université de Montpellier) for $\mu$-CT scan acquisitions, treatments, and reconstructions. This research was supported by the French "Agence Nationale de la Recherche" (ANR) in the framework of the GAARAnti program (ANR-17-CE31-0009) and of the LabEx CEBA (ANR-10-LABX-25-01). ISE-M publication $\mathrm{n}^{\circ} 2020-227$.

\section{BIBLIOGRAPHY}

Blackburn, D. C., Keefe, R. M., Vallejo-Pareja, M. C., VélezJuarbe, J., 2020. The earliest record of Caribbean frogs: a fossil coquí from Puerto Rico. Biological Letters 16, 20190947. https://doi.org/10.1098/rsbl.2019.0947

Brace, S., Turvey, S. T., Weksler, M., Hoogland, M. L. P., Barnes, I., 2015. Unexpected evolutionary diversity in a recently extinct Caribbean mammal radiation. Proceedings of the Royal Society of London, B 282, 20142371. https://doi.org/10.1098/rspb.201 4.2371

Courcelle, M., Tilak, M.-K., Leite, Y. L. R., Douzery, E. J. P., Fabre, P.-H., 2019. Digging for the spiny rat and hutia phylogeny using a gene capture approach, with the description of a new mammal subfamily. Molecular Phylogenetics and Evolution 136, 241-253. https://doi.org/10.1016/j.ympev.2019. 03.007

Delsuc, F., Kuch, M., Gibb, G. C., Karpinski, E., Hackenberger, D., Szpak, P., Martinez, J. G., Mead, J. I., McDonald, H. G., MacPhee, R. D. E., Billet, G., Hautier, L., Poinar, H. N., 2019. Ancient mitogenomes reveal the evolutionary history and biogeography of sloths. Current Biology 29, 1-12. https://doi.org/10.1016/j.cub.2019.05.043

Iturralde-Vinent, M. A., MacPhee, R. D. E., 1999. Paleogeography of the Caribbean region: implications for Cenozoic biogeography. Bulletin of the American Museum of Natural History $238,1-95$.

Lebrun, R., 2018. MorphoDig, an open-source 3D freeware dedicated to biology. 5th International Paleontological Congress (IPC5) - The Fossil Week, July 9-13th, 2018 (Paris, France). Abstract volume, 399.

MacPhee, R. D. E., Iturralde-Vinent, M. A., 1995. Origin of the Greater Antillean land mammal fauna, 1: New Tertiary fossils from Cuba and Puerto Rico. American Museum Novitates 3141, 1-30.

MacPhee, R. D. E., Iturralde-Vinent, M. A., 2005. The interpretation of Caribbean paleogeography: reply to Hedges. In Alcover, J. A., Bover, P. (Eds), Proceedings of the International Symposium on Insular Vertebrate Evolution: the Palaeontological Approach. Balearic Islands: Monografies de la Societat d'Historia Natural de les Balears. pp. 175-184.

Marivaux, L., Vélez-Juarbe, J., Merzeraud, G., Pujos, F., Viñola López, L. W., Boivin, M., Santos-Mercado, H., Cruz, E. J., Grajales, A., Padilla, J., Vélez-Rosado, K. I., Philippon, M., Léticée, J.-L., Münch, P., Antoine, P.-O., 2020. Early Oligocene chinchilloid caviomorphs from Puerto Rico and the initial rodent colonization of the West Indies. Proceedings of the Royal Society B 287, 20192806. https://doi.org/10.1098/rspb.2019. 2806

Ortega-Ariza, D., Franseen, E. K., Santos-Mercado, H., Ramirez, W. R., Core-Suarez, E. E., 2015. Strontium isotope stratigraphy for Oligocene-Miocene carbonate systems in Puerto Rico and the Dominican Republic: implications for Caribbean processes affecting depositional history. The Journal of Geology 123, 539-560. https://doi.org/10.1086/683335

Presslee, S., Slater, G. J., Pujos, F., Forasiepi, A. M., Fischer, R., Molloy, K., Mackie, M., Olsen, J. V., Kramarz, A. G., Taglioretti, M., Scaglia, F., Lezcano, M., Lanata, J. L., Southon, J., Feranec, R., Bloch, J. I., Hajduk, A., Martin, F. M., SalasGismondi, R., Reguero, M. A., de Muizon, C., Greenwood, A., Chait, B. T., Penkman, K., Collins, M., MacPhee, R. D. E., 2019. Palaeoproteomics resolves sloth relationships. Nature Ecology and Evolution 3, 1121-1130. https://doi.org/10.1038/ s41559-019-0909-z

Vélez-Juarbe, J., Brochu, C. A., Santos, H., 2007. A gharial from the Oligocene of Puerto Rico: transoceanic dispersal in the history of a non-marine reptile. Proceedings of the Royal Society B 274, 1245-1254. https://doi.org/10.1098/rspb.2006 .0455

Vélez-Juarbe, J., Martin, T., MacPhee, R. D. E., Ortega-Ariza, D., 2014. The earliest Caribbean rodents: Oligocene caviomorphs from Puerto Rico. Journal of Vertebrate Paleontology 34, 157-163. https://doi.org/10.1080/02724634.2013.789039 


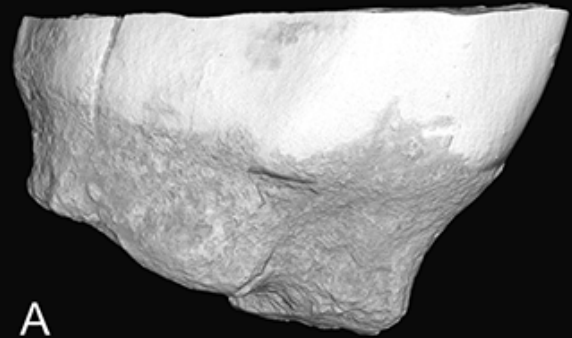

A
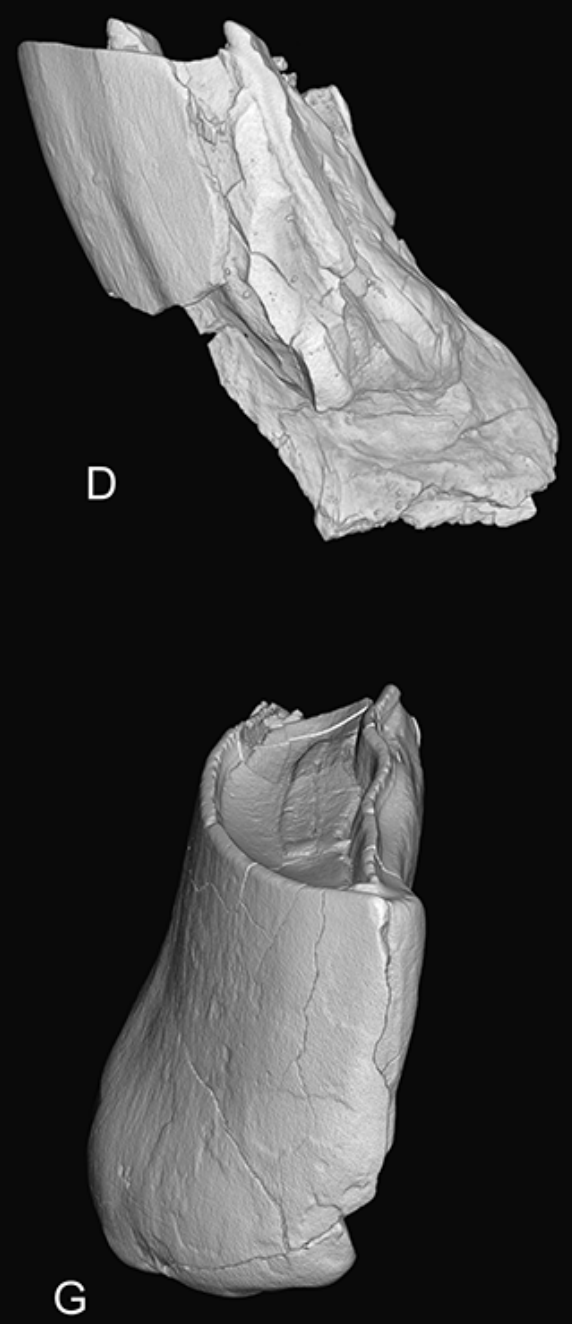
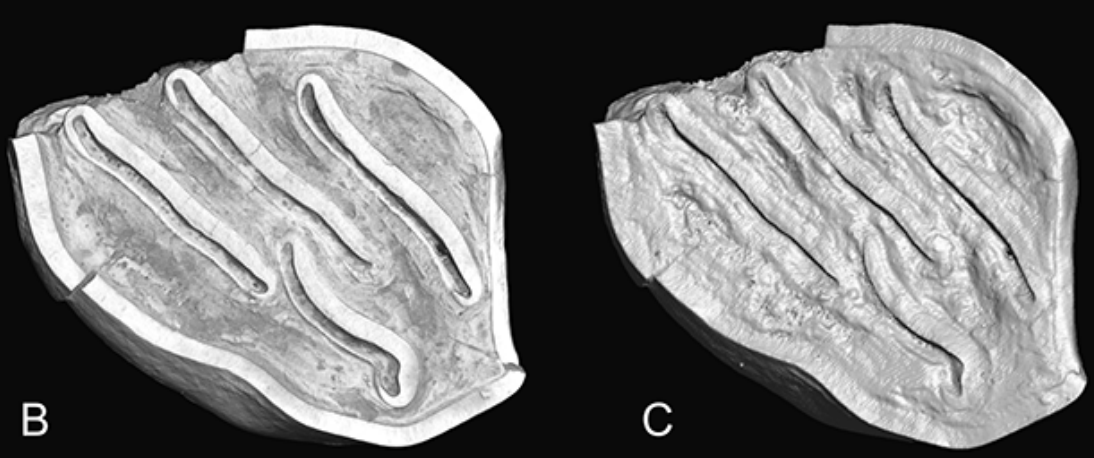

C
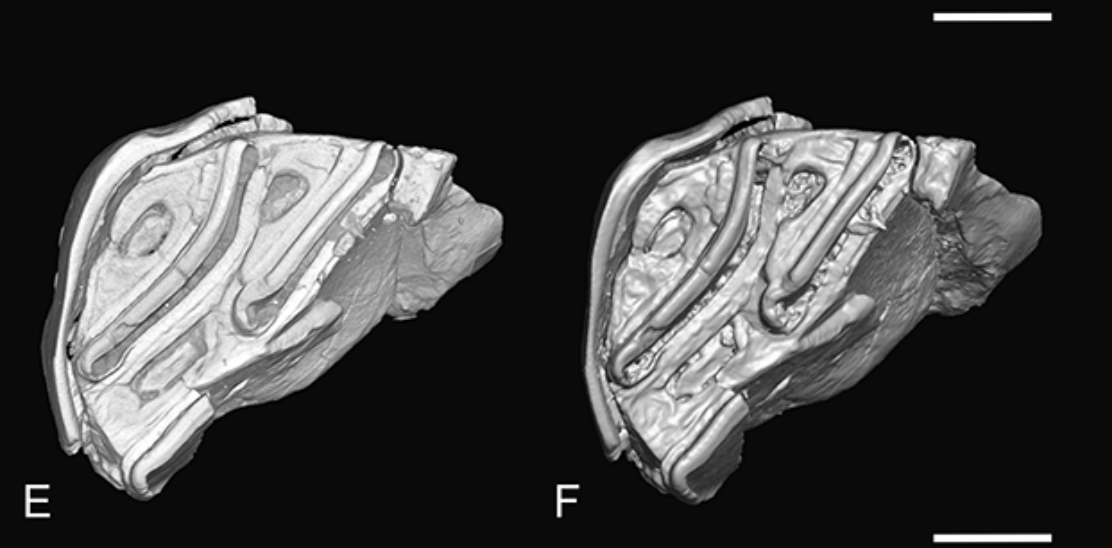
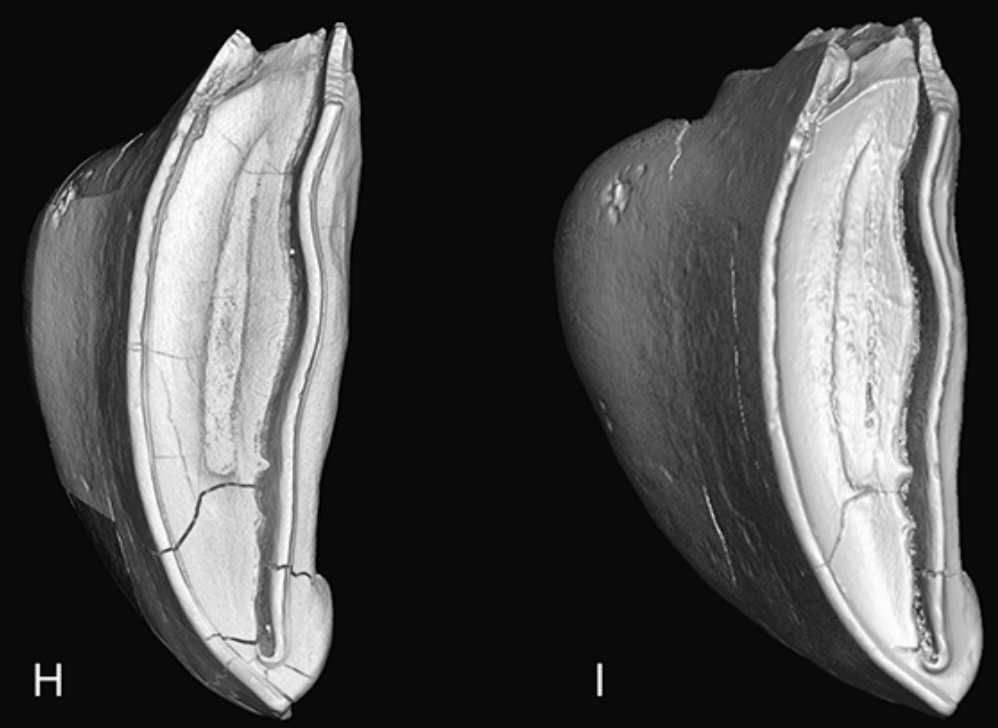

Figure 1. Fossil dental specimens of Borikenomys praecursor and Chinchilloidea gen. et sp. indet. from the late Early Oligocene of Puerto Rico (San Sebastian Formation). A-C) LACM 162447, right lower m3 in buccal (A) and occlusal (B-C) views; D-F) LACM 162446, fragment of lower molar (most of the mesial part) in lingual (D) and occlusal (E-F) views; G-I) LACM 162448, fragment of either an upper tooth (mesial laminae) or a lower tooth (distal laminae) in buccal or lingual (G) and occlusal (H-I) views. For each specimen, note the heterogeneous thickness of the enamel layer, which is thicker on the trailing edges than on the leading edges of laminae, a condition found primarily in chinchilloid rodents. Images are renderings of three-dimensional digital models of the fossil specimens, obtained by X-ray micro-computed tomography ( $\mu$-CT) surface reconstructions (A-B, D-E, and G-H are volume renderings of $\mu-\mathrm{CT}$ scan data; $\mathrm{C}, \mathrm{F}$, and I are renderings of segmented surfaces). Scale bar $=1$ $\mathrm{mm}$. 